\title{
Mail Archive System Model using Advantage Database Server (ADS)
}

\author{
Gloria Christina Manulangga ${ }^{\mathrm{a}, 1,{ }^{,},}$, Daniel Silli Bataona ${ }^{\mathrm{a}, 2}$, Folkes Eduard Laumal ${ }^{\mathrm{a}, 3}$ \\ ${ }^{a}$ Politeknik Negeri Kupang, Kupang, Indonesia \\ 1 gloriamanulangga@pnk.ac.id, ${ }^{2}$ danielbataona@pnk.ac.id, ${ }^{3}$ folkeslaumal76@gmail.com
}

\begin{tabular}{|c|c|}
\hline Article Info & ABSTRACT \\
\hline $\begin{array}{l}\text { Article history: } \\
\text { Received: January 7, } 2018 \\
\text { Revised: March 7, } 2018 \\
\text { Accepted: April 27, } 2018\end{array}$ & $\begin{array}{l}\text { Computerization process in archiving activity is completely needed and already many } \\
\text { kinds of archiving model application. One of those models is Advantage Database } \\
\text { Server (ADS) that support table system and data access based on SQL. This model is } \\
\text { also flexible and easy to apply on institution infrastructure. This research aims to } \\
\text { prove that the model can improve the productivity of an institution on archiving } \\
\text { activity. The development method used is a prototype with user acceptance system } \\
\text { testing. The result shows that there are average time reduction of about } 50.8 \% \text { on data } \\
\text { saving, } 95.1 \% \text { on data searching, and } 93.9 \% \text { on report printing. }\end{array}$ \\
\hline
\end{tabular}

Advantage Database Server

Archive model

Archive searching

\section{INTRODUCTION}

Nowadays, the conventional way on mail archive system with manual documentation should be converted to the advance system. The purpose of the archive management is for collecting information, searching information, securing archive, easy for access and improve the use of archive. Archive management is a control process, storage, and document security in a physical form or an electronic. An institution which have a good archive management will facilitate that institution on finding its track record (Ermawaty, 2013).

The main problem that often happens is from aspects of effectiveness and efficiency on finding the archive which have been documented. Besides the conventional way with one by one searching, another problem is to find a position of the archive saved.

Utilization of based on computer system is a compulsory needed because an advantage of this system is a swiftness on a data searching. The users can use the keyword to search a specific document according to its attribute (Cipta, Kurniasari, Labu, \& Selatan, 2013).

This research use Advantage Database Server (ADS) on archive system development. The use of ADS selected because of the support on Indexed Sequential Access Method
(ISAM) based on table and SQL database (Jensen \& Anderson, 2010).

Through this research expected can be a reference for an institution to fix or improve the existing system. Thereby, it can increase the productivity and shorten the time of documentation activity.

\section{LITERATURE REVIEW}

According to Ermawaty, the mail in any form is one of an archive (Ermawaty, 2013). The mail is closely related with an office activity. The mail is a media communication on a letter form which can used as evidence. Therefore, a good management is necessary to organize the documentation. Besides that, it also need a professional human resources, sufficient budget, good infrastructure, and supporting application system.

The electronic archive system based on client-server by Sugiarto developed to fulfil the demand of good archive management (Sugiarto, Silintowe, \& Kartika, 2013). This system using application tools AppServ for windows version 2.5, apache web server 2.2.3, PHP 5.1, MySQL 5.0 with, and phpMyAdmin 2.9.

According to the Gheni Abla et.al development, ITERDB is a data management system that designed to integrated ITER data archive and data access (Abla et al., 2014). This system 
used for data management that have not been processed by ITER system or data analysis work flow.

Andi Gunawan et.al develop a web-based management system of the government archive document (SIPADOP) in the government office of District Sidrap, South Sulawesi Province (Gunawan, 2016). This web-based application applied both online and offline, also used for organizing electronic documents in incoming or outcoming mail. Besides that, it also has an electronic disposition and electronic agenda with the main data that inputted through a scanner.

The finding has been done by R. Castro et.al as a part of the FPSC project prototype is about the archiving solution (Castro et al., 2012). Several main requirements of FPSC prototype are has a compatibility with the Ethernet network, so it can serve archive data by remote from storage location through Gigabit Ethernet standard networking.

TPSEPICS that developed by Yung-Sen Cheng et al. is a data archiving system based on SAN (Storage Area Network). It aims to store EPICS data which related to the historical data (Cheng, Liao, Chen, \& Hsu, 2014).

Digital Archive System for Long-Term Access (DALA) is a project to collaborate scientific digital data framework. The DALA development purposes are to collecting scientific data, data management, data analysis, data visualization, and data archiving (Riasetiawan \& Mahmood, 2010). This framework developed using GForge system that is a collaboration development environment.

Gill Kwon et.al in their research representing Korea Superconducting Tokamak Advanced Research (KSTAR) Real-time Data Archiving System (RTDAS) for real-time network system (Kwon, Lee, Lee, \& Hong, 2018). From most Fuzzy trial, a stable, low-latency real-time network is paramount to reaching a real-time control function. Network data archiving allows to accomplish performance analysis and network status. KSTAR and RTDAS developed to monitoring and archiving data in real-time that used for controlling plasma and send the diagnostic data to Plasma Control System (PCS).

\section{METHOD}

This research use prototype research method in system development stage. Next, user acceptance system testing which consists of alpha and beta testing applied in testing stage.

\section{A. System Development Method}

In this prototype development method there are several stages in its implementation. There are the stages in the archiving system development.

\section{1) Requirements Identification and System Design}

In this stage the first thing to do is problem identification in administration and the possible solution. Next, defining a software that will be develop and determine the system requirements and system design.

2) Build, testing, and prototype evaluation
In this stage start with the coding process to build the system. Next, the prototype system will be evaluate and test about the system feasibility. If the system not feasible yet, then will be re-coded and tested again until it is feasible to use. After the evaluation and testing stage passed, then the system can applied on the administration of mail archives.

\section{3) Prototype implementation}

The final version of prototype system will be implemented in this stage. The system will be implemented in an institution and in subdivision at the institution.

\section{4) Prototype development}

For further development, the system can be developed based on client-server, cloud computing, or mobile system.

\section{B. System Testing}

System testing is done by using user acceptance system testing type. This type of test is chosen so that the system can be applied to the appropriate environment and can meet the needs of the users of the administrative archive.

The user acceptance system testing has a two types of testing that is alpha and beta testing. The procedure of alpha and beta testing there are:

\section{1) Alpha testing}

This test is performed by users of the system in this case employees and students in the environment of the State Polytechnic Kupang. The alpha test done to ensure that the system can accepted and used on the archiving administration process.

\section{2) Beta testing}

Beta testing is performed by more competent users that is within the administration environment of State Polytechnic Kupang. This test determines whether the system is acceptable or should be redesigned for use. This testing uses quality dimension parameters (system content, system function, system structure, usability, capability, performance, compatibility, interoperability, and system security).

\section{SYSTEM DESIGN}

\section{A. context diagram}

The work flow of system model represented in context diagram form. Figure 1 shows the context diagram of the archiving system.

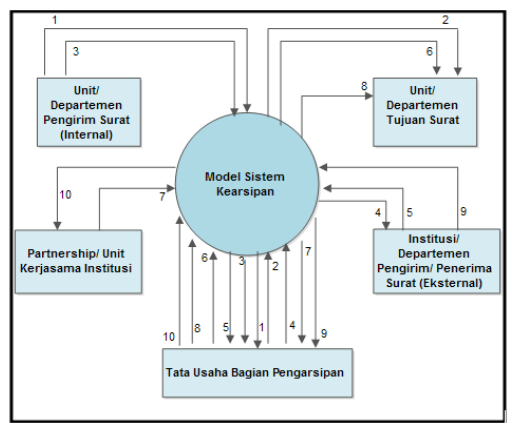

Fig. 1. Context diagram of archiving model system 
The explanation of the context diagram, there are:

1. The incoming mail from internal unit or department, then the mail will archived in archiving unit.

2. The archived mail will be forwarded to the recipient unit or department.

3. The mails sent from the sending unit or department, archiving first then sent to the recipient institution / department where this mail is a type of external.

4. The archived mail are then addressed to recipient institution or department (external mail).

5. The incoming mail which comes from external institution will be archived first.

6. After noted, the incoming mail will be forwarded to the recipients unit or department.

7. The mail which comes from the partnership will be archived first before forwarded to the recipient unit or department.

8. After the mail archived, it will be forwarded to the recipient unit or department.

9. External type of incoming mail which addressed to the institutional cooperation unit should be archived first on the system.

10. Those archived mails will be forwarded to the cooperation unit of institution.

\section{B. Entity Relationship Diagram}

The given permissions restrict each user from having different access to using this system model, where differences in the manipulation of permission access and data, reports, or attachment printing. Institutions and forms of letters are an indicator key in distinguishing the sender, recipient, and type of letter. The attachment provided is a reporting process in the form of a printed report and can be retrieved via report parameters that have been provided on the archival report menu (Figure 6).

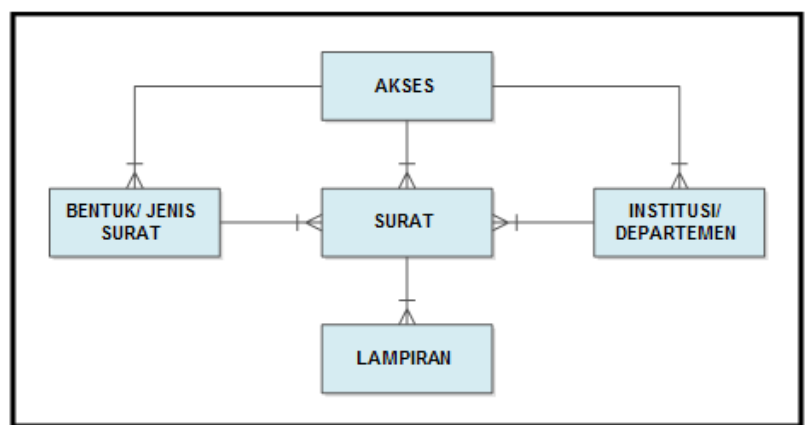

Fig. 2. Entity Relationship Diagram

\section{Layout System}

Process of data storing and searching can be seen in the layout system program, as showed in following figures. Figure 3 shows the archive data content preview. In this form, the user can fill the letter number, source of letter, the letter destination, case, and comment. The user also able to save and cancel the form input.

Figure 4 shows the searching page. The searching attributes are letter number, type, style, source, destination, case, and comment. The searching result showed in Figure 5.

Figure 6 shows the report of the letter. In this form user can print the letter into the hardcopy. The result of the report showed in Figure 7.

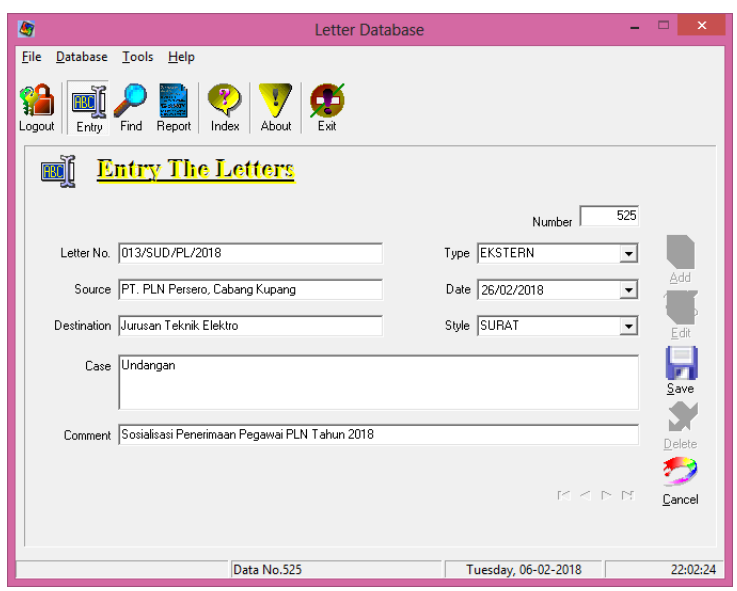

Fig. 3. archived data content preview

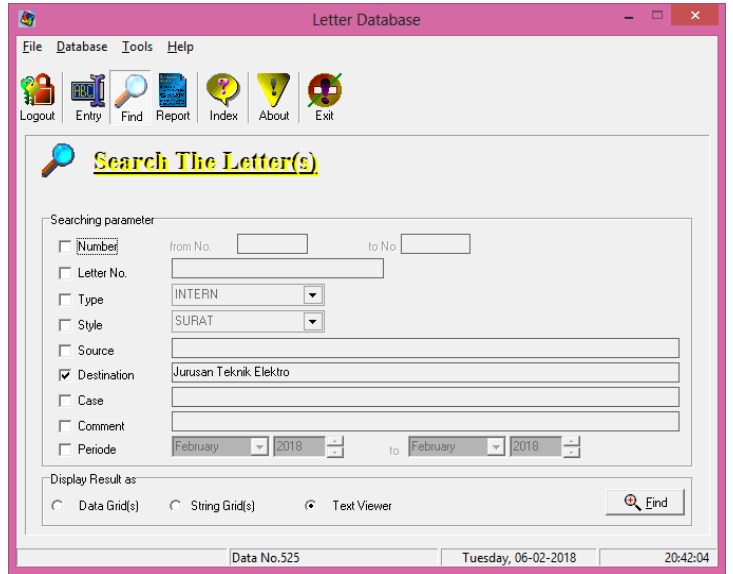

Fig. 4. Mail Search Archive preview 


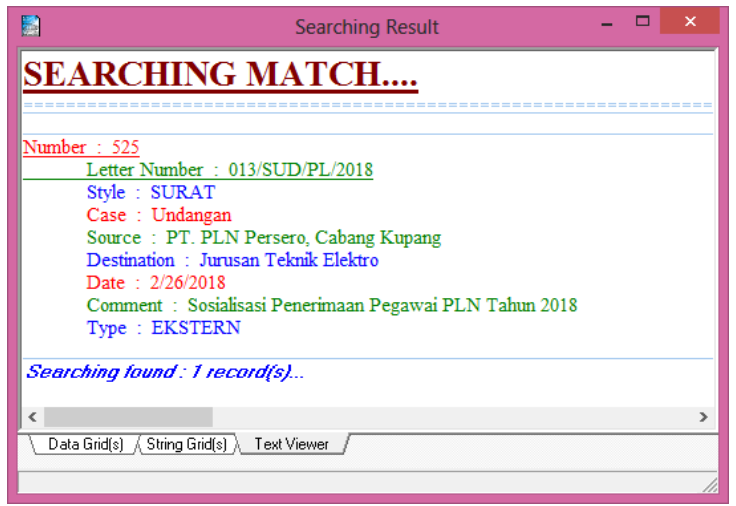

Fig. 5. Search result preview

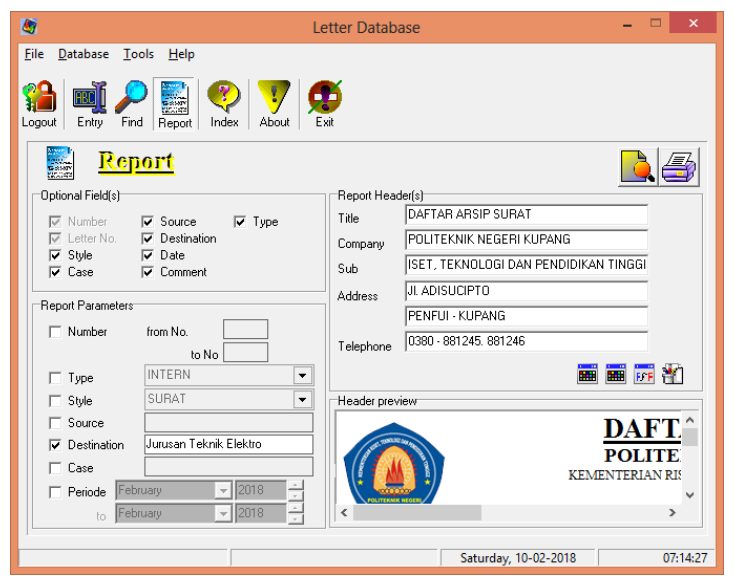

Fig. 6. Archive report menu preview

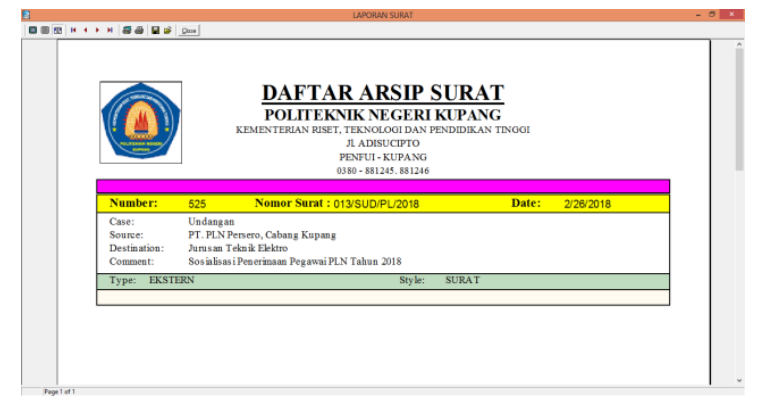

Fig. 7. Archive report and archive print preview

\section{RESULT}

This archive system is tested with user indicators with multiple backgrounds ie users who are familiar to using computer applications but still lay in archiving, users who are not used to using computer applications but are not familiar in conventional archiving, and users who are familiar to using computer applications in the field of filing system. These three backgrounds are represented by students, civil servants, and administrative personnel. Comparison of estimation are conventional archive system and archive system using ADS, the result can be seen in figure 8 .

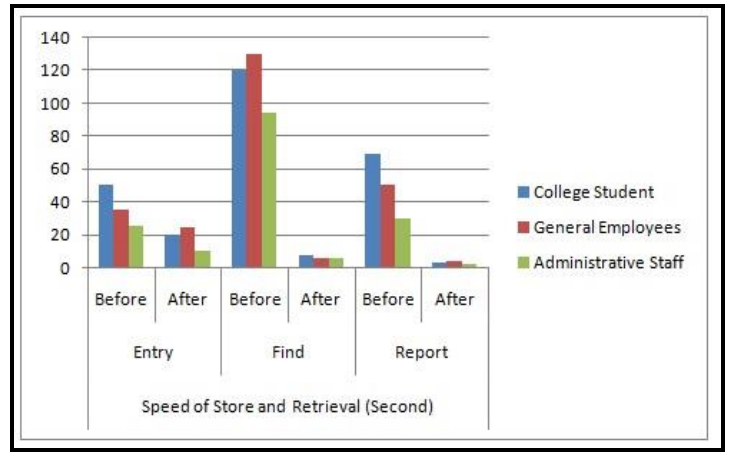

Fig. 8. Time Event Estimation Comparison of Archiving Activities

In the figure 8 shows that there is a decrease in time used in performing archiving process where the results of user acceptance system testing with the subjects ie students, general staff, and administrative personnel on the administration. The test results show the estimation needed before and after the use of archive system in the activities of archiving, file search, or reporting.

From the result also shows that there has been a decrease in estimated average time required in the process of archiving of $50.8 \%$, while for the search process of $95.1 \%$, and the reporting process in hard copy form of $93.9 \%$.

The search process shows the highest decrease in estimated time presentation because search parameters in this system provided by nine parameters, enabling to search with various keyword option or other parameter more variety. Compared to the old system where only the naming and numbering of archive folders based on the system of fiscal year. The system is made also equipped with the numbering system map, safe number, and the number of the file where the archive is located.

\section{CONCLUSION}

The use of ADS can be a solution for the institutions on their mail archiving activity. The testing result show that there are significantly time reduction on the whole process is above $50 \%$. If the application applied on every department of institution, it can be increase the productivity of that institution. The advantages of this application is the flexibility and easy use for various department or unit in institution. Because this system is still stand alone, the design of clientserver base is needed for further development.

\section{References}

Abla, G., Heber, G., Schissel, D. P., Robinson, D., Abadie, L., Wallander, A., \& Flanagan, S. M. (2014). ITERDB - the data archiving system for ITER. Fusion Engineering and Design, 89(5), 536-541.

Castro, R., Vega, J., Ruiz, M., De Arcas, G., Barrera, E., López, J. M., \& Makijarvi, P. (2012). NetCDF based data archiving system applied to ITER Fast Plant System Control prototype. Fusion Engineering and Design, 87(12), 2223-2228.

Cheng, Y. S., Liao, C. Y., Chen, J., \& Hsu, K. T. (2014). Implementation and 
performance analysis of the archive system for the Taiwan photon source project. In Computer, Consumer and Control (IS3C), 2014 International Symposium (pp. 368-371).

Cipta, W., Kurniasari, R., Labu, P., \& Selatan, J. (2013). Kembali Arsip, V(1), 60-67.

Ermawaty. (2013). Pengelolaan Surat Dan Tata Persuratan Dalam Arsip. Pelangi Pendidikan, 20(1), 83-88.

Gunawan, A. (2016). Pengembangan Model Pengelolaan Arsip ( Surat) dan Dokumen Pemerintah Berbasis Web pada Kantor Pemerintah Kabupaten Sidrap Provinsi Sulawesi Selatan. Sainsmat, 4(2).

Jensen, C., \& Anderson, L. (2010). Advantage Database Server: A Developer's Guide, 2nd Edition. CreateSpace Independent Publishing Platform.

Kwon, G., Lee, W., Lee, T., \& Hong, J. (2018). Development of a real-time data archive system for a KSTAR real-time network. Fusion Engineering and Design, 127, 202-206.

Riasetiawan, M., \& Mahmood, A. K. (2010). DALA project: Digital archive system for long term access. In Distributed Framework and Applications (DFmA), 2010 International Conference (pp. 1-5).

Sugiarto, A., Silintowe, Y. B., \& Kartika, L. N. (2013). Pengembangan Sistem Kearsipan Elektronik Berbasis Client-Server: Studi Pada Kantor Yayasan Perguruan Tinggi Kristen Satya Wacana. Jurnal Teknologi Informasi Aiti, 10(1), 46-61. 